\title{
Luminal-B breast cancer and novel therapeutic targets
}

\author{
Ben Tran and Philippe L Bedard*
}

\begin{abstract}
Gene expression profiling has led to a new molecular classification of breast cancer characterized by four intrinsic subtypes: basal-like, HER2-positive, luminal A, and luminal B. Despite expressing estrogen receptor, the luminal-B subtype confers increased risk of early relapse with endocrine therapy compared with the luminal-A subtype. Although luminal-B definitions vary, the hallmark appears to be increased expression of proliferation-related genes. Several biological pathways are identified as possible contributors to the poor outcomes, and novel agents targeting these pathways are being developed with aims to improve survival. We review the definition of luminal-B breast cancer, its pathological and clinical features, and potential targets for treatment.
\end{abstract}

\section{Introduction}

The National Cancer Institute defines personalized medicine as 'a form of medicine that uses information about a person's genes, proteins, and environment to prevent, diagnose, and treat disease' [1]. Personalized cancer medicine has existed in breast cancer since the late 1980s when benefits of tamoxifen were found to be limited to patients with tumors expressing estrogen receptors (ERs) [2]. This personalized treatment has advanced further in recent times through the discovery of erbB2/HER2 gene amplification and its subsequent targeted treatments such as trastuzumab and lapatinib [3,4].

Until very recently, personalized cancer medicine in breast cancer relied on only two predictive markers, ER and erbB2/HER2. The advent of gene expression profiling, however, has led to a paradigm shift in breast cancer medicine. Breast cancer is now recognized not as a single disease with variable morphology, but as at least four molecularly distinct neoplastic disorders: basal-like

*Correspondence: Philippe.Bedard@uhn.on.ca

Princess Margaret Hospital, 610 University Avenue, Toronto, Canada M5G 2 M9 breast cancer, HER2-positive breast cancer, luminal-A breast cancer, and luminal-B breast cancer [5-8]. Although the immediate additional clinical value of this molecular classification is limited by its close correlation to traditional methods of testing for ER and HER2, the identification of genetic aberrations that underlie molecularly distinct subclasses of breast cancer has revealed new therapeutic targets and has reshaped breast cancer clinical trial design.

The subtypes most in need of therapeutic advances are basal-like breast cancer and luminal-B breast cancer, where therapeutic resistance is common and where advances in molecular profiling have identified promising new therapeutic targets. In the present review article, we discuss the definition of luminal- $B$ breast cancer, the clinical behavior and pathological features of luminal-B breast cancer, and emerging molecular targets for improved therapy (see Table 1 for a summary).

\section{Defining luminal-B breast cancer}

Microarray technology has enabled better understanding of cancer biology at a molecular level through the interrogation of tens of thousands of expressed genes simultaneously. In breast cancer, hierarchical clustering of a series of breast cancers based upon a set of differently expressed intrinsic genes between individual patients led to the identification of a novel molecular classification of breast cancer [7]. The so-called intrinsic molecular classification of human breast cancer includes basal-like, HER2-positive, luminal-A and luminal-B subtypes. These subtypes have been associated with distinct pathological features and clinical outcome: basal-like breast cancer is predominantly triple-negative, with absent expression of ER, progesterone receptor (PR) and normal erbB2/HER2 gene copy number; HER2-positive breast cancer is erbB2/ HER2 gene amplified and is associated with poorer outcomes when untreated; and both luminal-A and luminal-B breast cancers are ER-positive, although luminal-B cancers have poorer outcomes [9].

The seminal work of Perou and colleagues initially identified molecular portraits of breast cancer based upon gene expression profiling of 65 breast cancer samples from 42 individual patients using cDNA 


\section{Table 1. Luminal-B breast cancer}

Genes overexpressed in gene expression profiling

ER and ER-regulated genes

Proliferation-related genes

Cell cycle genes

Histopathological features

ER-positive

High grade

High Ki-67

Clinical features

Poorer disease-free survival

Increased risk of early relapse

Predisposition to relapse in bone and pleura

Relative insensitivity to endocrine therapy compared with luminal-A subtype

Relative insensitivity to chemotherapy compared with basal-like and HER2-positive subtypes

$E R$, estrogen receptor.

microarrays [7]. Their classification was based upon the premise that individual differences in gene expression should be greater than differences in gene expression from paired tumor samples derived from the same patient. They identified a set of 496 genes that demonstrated significantly greater variation between individual tumors than within paired tumor samples from the same individual. When this intrinsic gene set was used to perform hierarchical clustering of their tumor samples, four subgroups were identified: basallike, based upon similarities in gene expression to basal epithelial cells in the normal breast; Erb-B2 positive, based upon increased expression of genes in the erbB2/ HER2 gene amplicon on chromosome 17q12; luminal, based upon similarities in gene expression to luminal epithelial cells in the normal breast; and normal breastlike, based upon the inclusion of three normal, nonmalignant breast samples. In this initial study, no distinction between luminal-A and luminal-B breast cancers was identified.

A subsequent study from the same group extended the sample size to 78 breast cancers (including 40 from the original publication) using hierarchical clustering with an intrinsic gene set of $456 \mathrm{cDNA}$ clones. Extension of the sample size allowed for the identification of subsets within the luminal cluster (47 tumors): luminal A (32 tumors), luminal B (five tumors), and luminal C (10 tumors) [8]. Luminal B and luminal C demonstrated lower expression of ER-related genes compared with luminal-A tumors, while luminal $\mathrm{C}$ was further distinguished from luminal $\mathrm{A}$ and luminal $\mathrm{B}$ by high expression of a set of genes shared with basal-like and
HER2-positive subtypes, but of unknown function [8]. Compared with luminal-A tumors, poorer outcomes were observed in luminal-B and luminal-C tumors. It is well recognized that hierarchical clustering based on a small sample number can result in unstable molecular classifications. Later studies failed to reproduce the luminal-C subtype and the luminal classification was collapsed into two subtypes: luminal-A with high expression of ER-regulated genes and favorable longterm outcome, and luminal-B with lower expression of ER-regulated genes and poorer long-term outcome.

Multiple gene expression studies have reproduced luminal-A and luminal-B subtypes. Both subtypes have expression patterns reminiscent of the luminal epithelial component of the breast, including expression of luminal cytokeratins 8/18, ER and genes associated with ER activation such as CCND1 (cyclin D1). The major molecular distinction between the two luminal subtypes is that, in general, luminal B has lower expression of ERrelated genes and higher expression of proliferative genes $[6,8,10]$. Luminal-B tumors also demonstrate increased expression of growth receptor signaling genes, although only $10 \%$ of tumors were HER2-positive by immunohistochemistry [11]. A review of several gene expression studies noted that approximately $20 \%$ of luminal-B breast cancers were HER2-positive by immunohistochemistry [5]. Since HER2-positive breast cancers are treated very differently from HER2-negative breast cancers, a clinically meaningful classifier of luminal-B breast cancer should not include HER2-positive breast cancers [9]. Approximately 30\% of HER2-positive tumors defined by immunohistochemistry are assigned to the luminal-B subtype. Most of the tumors are also ER-positive by immunohistochemistry or ESR1 gene expression [6,9]. The clinical relevance of whether an ER-positive breast cancer with overexpression of HER2 is classified as HER2-positive or as luminal B by the intrinsic molecular classification remains to be determined.

In many subsequent studies, luminal-B breast cancer has been defined as ER-positive breast cancer with increased proliferation [5]. In gene expression studies, proliferation genes such as CCNB1, MKI67 and MYBL2 are more highly expressed in luminal-B compared with luminal-A subtypes [12], correlating with a higher proportion of histological grade III also observed in luminal-B cancers [9].

Since the seminal paper of Perou and colleagues first identified the intrinsic molecular subtypes of breast cancer, there have been various single subtype predictors (SSPs) that have been developed to identify the molecular subtype of an individual breast cancer $[6,13,14]$. These SSPs differ in the intrinsic gene list that is used to define molecular classification. Recently, the reproducibility of subtype assignment across these three SSPs was 
evaluated by retrieving expression data from three publicly available datasets involving nearly 800 patients and performing two-way average-linkage hierarchical cluster analysis using five distinct intrinsic gene lists. Whilst the basal-like and HER2 subtypes could be reproducibly identified by independent observers, none of the classification systems could produce substantial agreement in subdividing luminal cancers [15]. A similar study by Weigelt and colleagues produced similar conclusions [16]. Although this lack of agreement is troublesome, it is perhaps not surprising as the initial molecular classification was based upon only 42 individuals with breast cancer [7].

Proliferation has been consistently identified as the most important feature of several prognostic multigene signatures, including the intrinsic molecular classification $[5,17]$. In ER-positive/HER2-negative tumors, proliferation is the strongest predictor of early relapse risk that differentiates high-risk luminal-B tumors from low-risk luminal-A tumors [5,18]. Whilst ER is bimodally expressed (meaning the overwhelming majority of cases are either completely ER-positive or unambiguously ERnegative) in breast cancer, thus allowing a meaningful cut-off point to be applied [19], proliferation-related genes are expressed along a unimodal continuum. This makes it extremely difficult to apply any meaningful cutoff point that differentiates between high and low proliferative tumors in a reproducible manner. This is evident in the differences in subtype assignment between luminal-B and luminal-A tumors across SSPs, where tumors with a level of proliferation around the median value may be inconsistently classified by SSPs that use different proliferation-driven intrinsic gene lists.

\section{Clinical features of luminal-B breast cancer}

Since the earliest studies of the intrinsic molecular subtypes in breast cancer, the defining feature of luminal$B$ breast cancer has been its poor outcome compared with the luminal-A subtype [7]. Overall survival in untreated luminal-B breast cancer is similar to the basallike and HER2-positive subgroups, which are widely recognized as high risk. One study used a 50-gene classifier to assign intrinsic subtypes to 761 untreated breast cancer patients, and correlated subtype with outcome. In a multivariate analysis of untreated early breast cancer, using the luminal-A subtype as a reference, luminal-B breast cancers were demonstrated to have a hazard ratio of $2.43(P<0.0001)$ for relapse-free survival (RFS), similar to hazard ratios for erbB2/HER2 amplified $(2.53, P=0.00012)$ tumors [13].

The increased relapse risk associated with the luminalB phenotype appears to be limited to the early period after surgery. Since increased proliferation is the hallmark of luminal-B cancer [20], it is not surprising that increased relapse rates observed in luminal-B tumors are limited to the first 5 years after diagnosis, with no difference in distant relapse beyond 5 years [21]. In a series of 831 untreated node-negative breast cancers, curated from five publicly available gene expression datasets, we found the hazard ratio for distant metastases of luminal-B subtype compared with luminal-A subtype to be $2.86(P<0.01)$ for early metastases $(<5$ years $)$ and $0.65(P=$ nonsignificant $)$ for late metastases $(\geq 5$ years $)$ (Table 2).

There are differences in the anatomic sites of relapse according to molecular subtypes. The increased incidence of brain metastases in HER2-positive and basallike breast cancer is well recognized [22,23]. Luminal breast cancers appear to have a predilection for metastasis to bone and pleura. In a small study of 81 patients with metastatic breast cancer, no differences in sites of metastasis were observed between luminal-B and luminal-A breast cancers [24].

Several studies have suggested luminal-B breast cancer is relatively insensitive to endocrine therapy compared with luminal-A breast cancer, and to chemotherapy compared with HER2-enriched and basal-like breast cancers. Five studies examined the pathological complete response (pCR) rate following preoperative chemotherapy according to molecular subtype. Table 3 compares the pCR for each molecular subtype in each study and demonstrates that the $\mathrm{pCR}$ rate is consistently lower in luminal-B breast cancer when compared with HER2 and basal-like subtypes [25-29]. There were important methodological differences in these studies, including the method of subtype definition of the luminal-B subgroup (particularly the inclusion of ER-positive and HER2positive breast cancer in some studies), and differences in chemotherapy received.

Although luminal-B tumors are characterized by high proliferation, the likelihood of achieving $\mathrm{PCR}$ with preoperative chemotherapy is exceedingly low. In other high-risk breast cancer subtypes, pCR is a robust surrogate endpoint for disease-free survival and overall survival $[30,31]$. It is not clear whether pCR is a meaningful surrogate endpoint in luminal tumors. Paradoxically, large, low proliferative ER-positive tumors categorized with a low recurrence score by the OncotypeDx ${ }^{\mathrm{mm}}$ assay that fail to achieve $\mathrm{pCR}$ with preoperative chemotherapy experience excellent long-term survival [32]. In this study, there was no difference in long-term outcome for low recurrence score tumors that achieved $\mathrm{pCR}$ with preoperative chemotherapy compared with tumors in which there is residual invasive disease, although there were few low recurrence score tumors in this study that achieved pCR.

Response to endocrine therapy in the preoperative setting has also been explored as a surrogate marker for 
Table 2. Risk of early versus late relapse in molecular subtypes of breast cancer

\begin{tabular}{|c|c|c|c|c|c|c|}
\hline & \multicolumn{3}{|c|}{$\begin{array}{c}\text { Early }(<5 \text { years }) \text { distant } \\
\text { metastases }(n=831)\end{array}$} & \multicolumn{3}{|c|}{$\begin{array}{l}\text { Late }(\geq 5 \text { years) distant } \\
\text { metastases }(n=652)\end{array}$} \\
\hline & HR & $95 \% \mathrm{Cl}$ & $P$ value & HR & $95 \% \mathrm{Cl}$ & $P$ value \\
\hline \multicolumn{7}{|l|}{ Age } \\
\hline ( $<50$ years vs. $\geq 50$ years) & 0.77 & $(0.56,1.06)$ & NS & 1.65 & $(0.97,2.81)$ & NS \\
\hline \multicolumn{7}{|l|}{ Tumor size } \\
\hline$(\leq 2 \mathrm{~cm}$ vs. $>2 \mathrm{~cm})$ & 1.31 & $(0.91,1.86)$ & NS & 1.18 & $(0.69,2.01)$ & NS \\
\hline \multicolumn{7}{|l|}{ Histological grade } \\
\hline (2 vs. 1) & 5.02 & $(1.80,14.0)$ & $<0.01$ & 0.92 & $(0.48,1.76)$ & NS \\
\hline (3 vs. 1) & 7.22 & $(2.59,20.2)$ & $<0.01$ & 0.70 & $(0.31,1.60)$ & NS \\
\hline \multicolumn{7}{|l|}{ Molecular subtype } \\
\hline Luminal-A & 1 & - & - & 1 & - & - \\
\hline Luminal-B & 2.86 & $(1.70,4.80)$ & $<0.01$ & 0.65 & $(0.24,1.72)$ & NS \\
\hline HER2-positive & 2.62 & $(1.50,4.60)$ & $<0.01$ & 1.41 & $(0.64,3.12)$ & NS \\
\hline Basal-like & 2.83 & $(1.92,4.82)$ & $<0.01$ & 0.96 & $(0.54,1.70)$ & NS \\
\hline
\end{tabular}

Data from five publicly available datasets from patients with node-negative tumors who did not receive adjuvant systemic therapy. Molecular subtype assignment according to the subtype clustering method [17]. Cl, confidence interval; HR, hazard ratio; NS, nonsignificant.

Table 3. Pathological complete response rates post neoadjuvant chemotherapy in molecular subtypes of breast cancer

\begin{tabular}{|c|c|c|c|c|c|c|c|}
\hline \multirow[b]{2}{*}{ Author } & \multirow[b]{2}{*}{$n$} & \multirow[b]{2}{*}{$\begin{array}{l}\text { Method of molecular } \\
\text { classification }\end{array}$} & \multirow[b]{2}{*}{ Defining luminal $B$} & \multicolumn{4}{|c|}{ Pathological complete response rate (\%) } \\
\hline & & & & $\underset{A}{\text { Luminal }}$ & $\underset{B}{\text { Luminal }}$ & $\begin{array}{l}\text { HER2- } \\
\text { positive }\end{array}$ & $\begin{array}{l}\text { Basal- } \\
\text { like }\end{array}$ \\
\hline $\begin{array}{l}\text { Esserman and } \\
\text { colleagues [25] }\end{array}$ & 144 & Microarray & $\begin{array}{l}\text { Intrinsic gene set and hierarchical } \\
\text { clustering (included some HER2 }{ }^{+} \text {) }\end{array}$ & -5 & 13 & 55 & 34 \\
\hline $\begin{array}{l}\text { De Ronde and } \\
\text { colleagues [26] }\end{array}$ & 191 & Microarray & $\begin{array}{l}\text { Intrinsic gene set and hierarchical } \\
\text { clustering (included some HER2 }{ }^{+} \text {) }\end{array}$ & 7 & 7 & 44 & 44 \\
\hline $\begin{array}{l}\text { Bhargava and } \\
\text { colleagues [27] }\end{array}$ & 359 & IHC surrogate markers & ER-, HER2- & 2 & 1 & 33 & 30 \\
\hline $\begin{array}{l}\text { Carey and } \\
\text { colleagues [28] }\end{array}$ & 107 & IHC surrogate markers & $\mathrm{ER}^{+}, \mathrm{HER} 2^{+}$ & 0 & 15 & 36 & 27 \\
\hline $\begin{array}{l}\text { Rouzier and } \\
\text { colleagues [29] }\end{array}$ & 82 & Microarray & $\begin{array}{l}\text { Intrinsic gene set and hierarchical } \\
\text { clustering (included some HER2 }\end{array}$ & $7^{\mathrm{a}}$ & $7^{\mathrm{a}}$ & 45 & 45 \\
\hline
\end{tabular}

ER, estrogen receptor; IHC, immunohistochemistry. ${ }^{\text {an }}$ Rouzier and colleagues [29], luminal-A and luminal-B subtypes were grouped together as the luminal subtype.

long-term outcomes. In ER-positive tumors, the level of residual proliferation after 10 to 14 days of preoperative endocrine therapy is prognostic for long-term RFS [33]. A correlative substudy of the IMPACT trial analyzed 158 patients with paired biopsies (baseline and 2 weeks after endocrine therapy), and found that the absolute value of residual proliferation after short-term endocrine therapy, as assessed by the percentage of Ki-67 immunostaining, was strongly predictive of RFS; Ki-67 index $<2.7 \%$ was associated with favorable RFS. Interestingly, the Ki-67 index measured after 10 to 14 days of endocrine therapy was more predictive of long-term RFS than the pretreatment Ki-67 index [34]. pCR after preoperative endocrine therapy is rare [33,35-37]. Whether clinical or radiographic response to preoperative endocrine therapy is predictive of long-term outcome in ER-positive disease is not firmly established.
Despite the problems with subtype classification, the luminal-B subtype remains a clinically important classification of breast cancer with prognostic and potential predictive implications. Weigelt and colleagues suggest that standardized methods and definitions for identification of breast cancer molecular subtypes are necessary to incorporate molecular subtype classification into routine clinical practice [16]. HER2 and basal-like subtypes can already be identified using fluorescence in situ hybridization and immunostaining for ER, PR and HER2. With regard to differentiating between luminal-A and luminal-B subtypes, various authors have tried to define more pragmatic criteria that can broadly be applied to clinical practice. Some studies have used the level of ER expression to differentiate luminal-B from luminal-A subtypes [27], but this does not take into account the level of proliferation. 
One study explored the use of the Ki-67 index as a potential unidimensional proliferation marker that could successfully differentiate luminal-B tumors from luminalA tumors in a clinically practical way [12]. Subtypes were assigned for a cohort of 357 breast cancers using microarray-based gene expression profiling, and the Ki-67 status, hormone receptor status and HER2 status were concurrently determined by immunohistochemistry. The authors used receiver operating characteristic curves to determine the Ki-67 cut-off point that distinguished luminal-A from luminal-B tumors, then applied it to an independent microarray series of 4,046 breast cancers. They were able to successfully demonstrate using immunohistochemistry that determining the Ki-67 index can distinguish between the two subtypes [12]. However, arbitrarily applying a clinically relevant cut-off point to a continuous variable such as $\mathrm{Ki}-67$ that is unimodally distributed is problematic. Ki-67 immunohistochemistry is also limited by low reproducibility between laboratories, ongoing debate over both the optimal antibody for testing and the method for cell counting (manual versus automated), in addition to potential problems resulting from tumor heterogeneity [38]. Multigene prognostic assays, such as OncotypeDx ${ }^{\mathrm{TM}}$, are currently used to assess proliferation in providing independent prognostic information in early breast cancer [39]. Given their level of reproducibility and less potential for influence by tumor heterogeneity, these assays may have potential advantages over a unidimensional marker such as Ki-67 in assigning subtype classification.

\section{Potential targets in luminal-B breast cancer Insulin-like growth factor signaling}

In cancer, ligand activation of the insulin-like growth factor 1 receptor (IGF-1R) and its downstream pathways (phosphoinositide 3-kinase (PI3K)/AKT/mammalian target of rapamycin (mTOR) and Ras/Raf/MEK/ERK) stimulates tumor proliferation, survival, transformation, metastasis and angiogenesis [40]. Laboratory and epidemiological studies have demonstrated a link between cancer and insulin-like growth factor 1 (IGF-1) signaling [41]. IGF-1R is expressed in the majority of breast cancer (90 to 95\%) and is often co-expressed with ER [42]. Cross-talk between ER and IGF-1R plays a critical role in tamoxifen resistance. Increased circulating plasma levels of IGF-1, a ligand for IGF-1R, identify women at increased risk of relapse on adjuvant tamoxifen [41]. Activation of IGF-1R signaling is associated with loss of PR expression, which itself is associated with high proliferative luminal$\mathrm{B}$ breast cancer, and with resistance to tamoxifeninduced apoptosis [43]. Creighton and colleagues derived a signature of more than 800 genes whose expression was significantly altered after exogenous IGF-1 stimulation in ER-positive MCF7 cells [44]. Activation of this IGF-1 signature was seen in approximately 25\% of ER-positive breast cancers and was associated with an increased risk of recurrence. Similar findings were reported by Ignatiadis and colleagues with their 142-gene in silico signature of IGF-1 activation that was more commonly found in luminal-B tumors compared with luminal-A tumors [45].

Inhibition of IGF-1R signaling demonstrates synergistic activity in combination with endocrine therapy in preclinical models of ER-positive breast cancer $[43,46]$. Various approaches to interrupting the IGF-1 signaling axis have been developed. Although potential targets include growth hormone and growth-hormone-releasing hormone, the most advanced therapeutic approach has been the development of antibodies against IGF-1R that block IGF-1 ligand-mediated activation and smallmolecule inhibitors of the IGF-1R tyrosine kinase domain [47]. Table 4 outlines IGF-1R-targeted therapies that are being investigated in ER-positive breast cancer and other solid tumors. The first preliminary report of a randomized phase II trial of exemestane or fulvestrant and AMG-479, a fully human monoclonal antibody against IGF-1R, or matching placebo was presented at the 2010 San Antonio Breast Cancer Symposium [48]. This study involved 156 patients with ER-positive metastatic breast cancer who had progressed following first-line endocrine therapy for advanced disease or who had relapsed within 12 months of completing adjuvant endocrine therapy. This study failed to meet its primary endpoint, as the addition of AMG-479 did not improve progression-free survival. The median progression-free survival for AMG-479 + endocrine therapy was 3.9 months, versus 5.7 months for placebo + endocrine therapy (hazard ratio $=1.17, P=0.44)$. Correlative studies of this trial and other ongoing studies will be essential to determine whether there is a signal of activity for IGF-1R inhibition in patients with luminal-B-like features, such as increased proliferation measured by Ki-67 immunostaining.

\section{Fibroblast growth factor signaling}

The fibroblast growth factor (FGF) signaling system includes 22 ligands and four receptors [49], and is a highly complex growth factor signaling pathway that is responsible for many functions, including cell proliferation, survival and migration, through differing downstream molecules or pathways [49]. Multiple studies indicate that FGF may also be involved in angiogenesis. One study demonstrated that the ligand FGF2 stimulates migration and proliferation of endothelial cells, whilst another study demonstrated that, under anti-vascular endothelial growth factor therapy, tumor angiogenesis can switch from vascular endothelial growth factor receptor dependence to fibroblast growth factor receptor (FGFR) dependence via upregulating FGF2, possibly explaining resistance to vascular endothelial growth 
Table 4. Targeted treatment in luminal-B breast cancer

\begin{tabular}{|c|c|c|c|c|c|c|}
\hline Pathway & Agent & Supplier & Class & Phase & Study design & Eligible population \\
\hline \multirow[t]{6}{*}{ IGF } & BMS-754807 & BristolMyersSquibb & |GF-1R/IRTKI & $\|$ & BMS-754807 \pm letrozole & $\begin{array}{l}\text { ER-positive locally advanced/metastatic } \\
\text { breast cancer, progressed on prior } \\
\text { nonsteroidal aromatase inhibitors }\end{array}$ \\
\hline & Cixutumumab & ImClone & IGF-1R mAb & $|/| \mid$ & $\begin{array}{l}\text { Cixutumumab and } \\
\text { temsirolimus }\end{array}$ & $\begin{array}{l}\text { Locally advanced/metastatic breast cancer } \\
\text { progressed on one or two chemotherapy } \\
\text { lines }\end{array}$ \\
\hline & MK-0646 & Merck & IGF-1R mAb & $|/| \mid$ & $\begin{array}{l}\text { MK-0646 and fulvestrant and } \\
\text { dasatinib }\end{array}$ & $\begin{array}{l}\text { Locally advanced/metastatic ER-positive } \\
\text { breast cancer with no previous treatment in } \\
\text { metastatic setting }\end{array}$ \\
\hline & Dalotuzumab & Merck & IGF-1R mAb & $\|$ & $\begin{array}{l}\text { Dalotuzumab and } \\
\text { ridaforolimus versus standard } \\
\text { care }\end{array}$ & $\begin{array}{l}\text { ER-positive locally advanced/metastatic } \\
\text { breast cancer, progressed on at least one line } \\
\text { of endocrine therapy }\end{array}$ \\
\hline & OSI-906 & OSI & |GF-1R/IRTKI & $\|$ & $\begin{array}{l}\text { OSI-906 and endocrine } \\
\text { therapy } \pm \text { erlotinib }\end{array}$ & $\begin{array}{l}\text { ER-positive metastatic breast cancer, treated } \\
\text { with } \leq 4 \text { chemotherapy regimens }\end{array}$ \\
\hline & CP-758171 & Pfizer & |GF-1RTK| & I & $\begin{array}{l}\text { CP-758171 for two cycles } \\
\text { prior to curative surgery }\end{array}$ & Operable early breast cancer \\
\hline \multirow[t]{2}{*}{ FGF } & TKI-258 & Novartis & FGFR/VEGFRTKI & $\|$ & TKI-259 single agent & $\begin{array}{l}\text { HER2-negative, FGFR1 amplified and FGFR1 } \\
\text { normal metastatic breast cancer }\end{array}$ \\
\hline & AZD-4547 & Astra Zeneca & FGFRTKI & $\|$ & Exemestane \pm AZD-4547 & $\begin{array}{l}\text { ER-positive locally advanced/metastatic } \\
\text { breast cancer with high levels of FGFR1 } \\
\text { expression }\end{array}$ \\
\hline \multirow[t]{4}{*}{ PI3KJAKT } & MK-2206 & Merck & AKT inhibitor & $\|$ & MK-2206 single agent & $\begin{array}{l}\text { Metastatic breast cancer with PIK3CA } \\
\text { mutation and/or PTEN loss, progressed on at } \\
\text { least one line of therapy }\end{array}$ \\
\hline & MK-2206 & Merck & AKT inhibitor & $\|$ & $\begin{array}{l}\text { MK-2206 and endocrine } \\
\text { therapy }\end{array}$ & $\begin{array}{l}\text { ER-positive metastatic breast cancer } \\
\text { progressed on endocrine therapy }\end{array}$ \\
\hline & $X L-147$ & Exelixis & PI3K inhibitor & $\|$ & XL-147 and letrozole & $\begin{array}{l}\text { ER-positive metastatic breast cancer } \\
\text { refractory to nonsteroidal aromatase } \\
\text { inhibitors }\end{array}$ \\
\hline & $X L-765$ & Exelixis & $\begin{array}{l}\mathrm{PI} 3 \mathrm{~K} / \mathrm{mTOR} \\
\text { inhibitor }\end{array}$ & $\|$ & XL-765 and letrozole & $\begin{array}{l}\text { ER-positive metastatic breast cancer } \\
\text { refractory to nonsteroidal aromatase } \\
\text { inhibitors }\end{array}$ \\
\hline
\end{tabular}

$E R$, estrogen receptor; FGF, fibroblast growth factor; FGFR, fibroblast growth factor receptor; IGF, insulin-like growth factor; IGF-1R, insulin-like growth factor 1 receptor; $\mathrm{mAb}$, monoclonal antibody; mTOR, mammalian target of rapamycin; PI3K, phosphoinositide 3-kinase; TKI, tyrosine kinase inhibitor; VEGFR, vascular endothelial growth factor.

factor-targeted agents [50,51]. Whether it is through cell proliferation, survival, migration or angiogenesis, the FGF pathway clearly has oncogenic roles in many cancers. These roles occur through various genetic aberrations that include amplifications, activating mutations, chromosomal translocations, SNPs and aberrant splicing at the post-transcriptional level.

In breast cancer, changes to FGF signaling are considered important for oncogenesis, mainly through amplification of FGFR1 and FGFR2. Following erbB2/ HER2, FGFR1 is amongst the most commonly amplified genes in breast cancer, present in up to $10 \%$ of all breast cancers [52]. Various reports have shown that FGFR1 amplification is most commonly associated with ER expression, the absence of HER2 overexpression and lobular histology [53,54]. Additionally, the FGFR2 gene is amplified in approximately 1 to $2 \%$ of breast cancers [52]. Genome-wide association studies have also shown that inherited SNPs in the FGFR2 gene are associated with an increased risk of developing ER-positive breast cancer, probably through an increase in FGFR2 transcription [52]. Although activating mutations in FGFR3 and FGFR4 occur in many types of human tumors, they seem to be rare in breast cancer [49].

Recent data suggest that the luminal-B subtype is enriched for FGFR1 gene amplification [52]. One study examined tumors from two independent series of breast cancer for FGFR1 amplification, demonstrating that FGFR1-amplified cancers are frequently PR-negative, have a high proliferative rate assessed by Ki-67 immunostaining and are present in 16 to $27 \%$ of luminal-B breast cancer [53]. Furthermore, the same study demonstrated that FGFR1-amplified breast cancer cell lines have both enhanced ligand-dependent and ligand-independent signaling, and are dependent upon FGFR signaling for anchorage-independent growth [53]. These authors also demonstrated that FGFR1-amplified cells were resistant to endocrine therapy, but this could be reversed by knockdown of FGFR1 [53]. Other studies have also observed that resistance to endocrine therapy can be 
reversed through both knockdown of FGFR1 expression and the use of a small molecule FGFR tyrosine kinase inhibitor [55]. These findings all suggest that the FGF pathway, and more specifically FGFR 1 gene amplification, may be a major contributor to the poor prognosis observed in luminal-B breast cancer, through increased proliferation and resistance to endocrine therapy.

Preclinical models of breast cancer cells amplified for FGFR1 or FGFR2 have demonstrated sensitivity to inhibition of FGFR [49]. This has led to several proof-ofconcept early-phase clinical trials using FGFR inhibitors. Several antibodies and small-molecule inhibitors of FGFR are currently in clinical testing. First-generation tyrosine kinase inhibitors also inhibit VEGFR2 due to structural similarity between the two tyrosine kinase domains [52]. Table 4 lists some of the current agents targeting the FGF pathway in breast cancer clinical trials. An important challenge for all of these studies is the identification of patients whose tumors harbor genetic amplification of FGFR1 or FGFR2. Like erbB2/HER2, chromosome in situ hybridization and fluorescence in situ hybridization are the dominant methods used to identify gene amplification in paraffin-embedded tumor samples.

\section{Phosphoinositide 3-kinase signaling}

Deregulated PI3K signaling has been implicated in many aspects of carcinogenesis [56]. Genetic aberrations along the pathway can occur anywhere from the upstream growth factor receptors to downstream target molecules, regulatory molecules and PI3K itself [56]. These genetic aberrations have the potential to change a number of cell functions that contribute to the transformed phenotype, including cell growth and proliferation, differentiation, cell survival, adhesion and cell motility [56]. Subsequently, the PI3K pathway - including its enzymes, targets and regulators - is considered an important potential therapeutic target in cancer.

In breast cancer, the PI3K pathway is frequently activated. Amplification of upstream receptors such as erbB2/HER2, loss of negative regulators such as PTEN, amplification of downstream targets such as $A k t$, and activating mutations or genetic amplification of the $\alpha$ catalytic subunit of PI3K (PIK3CA) have all been described in breast cancer. PIK3CA somatic mutations occur in approximately $25 \%$ of breast cancer $[57,58]$. In luminal$B$ breast cancer, the role of PI3K signaling is being defined. There appear to be no differences in the frequency of PIK3CA mutation between luminal-A and luminal-B breast cancers [58]. A recent preclinical study has demonstrated that increased expression of PI3K pathway genes is a feature of luminal-B breast cancer [59]. Growth inhibition induced by endocrine therapy in luminal-B breast cancer cell lines could be significantly increased by adding a selective PI3K inhibitor, suggesting that PI3K inhibitors may have a role in luminal-B breast cancer [59].

In breast cancer, the initial studies targeting the PI3K pathway involved rapamycin analogs or mTOR inhibitors. A phase II study of ER-positive breast cancer in the neoadjuvant setting compared 4 months of letrozole treatment with 4 months of letrozole and everolimus treatment, an oral mTOR inhibitor [36]. Although the rate of sonographic response was only marginally improved with the addition of everolimus to letrozole (68\% vs. $59 \%$, $P=0.062)$, there was a much greater improvement in antiproliferative response, defined as day $15 \mathrm{Ki}-67$ immunostaining $<2.7 \%$ ( $57 \%$ vs. $30 \%, P<0.01)$. The authors also noted that the rate of anti-proliferative response in the everolimus and letrozole arm was higher in tumors with PIK3CA mutations [36].

Recently, a negative intracellular signaling feedback loop between the mTOR complex 1 and the IGF-1 signaling axis has been discovered [60]. Intracellular levels of IRS1, a key mediator of IGF-1R signaling, are increased when mTOR complex 1 is inhibited by everolimus and other similar mTOR inhibitors, leading to paradoxical activation of Akt [61]. Preclinical models suggest robust activity for dual IGF-1R and mTOR inhibition [62,63]. A recent phase I study demonstrated that this combined therapy may be effective in breast cancer, where five out of 23 breast cancer patients had either partial response, prolonged stable disease or partial metabolic response [64]. The combination appeared particularly active in luminal-B like breast cancer - defined as ER-positive with Ki-67 immunostaining $\geq 15 \%$ - as three out of 10 patients in this trial, all of whom were heavily pretreated, achieved a partial response by the Response Evaluation Criteria in Solid Tumors.

There is great enthusiasm for highly specific PI3K inhibitors that are currently in early development. They range from pure pan-PI3K inhibitors to isoform-specific PI3K inhibitors, to dual inhibitors of both PI3K and mTOR, to Akt inhibitors. Currently, most early-phase studies using these agents attempt to select patients with genetic aberrations in this pathway. A recent preclinical study, however, suggested that PIK3CA mutation, but not PTEN loss, confers sensitivity to mTOR inhibitors [65]. In the clinical setting, one study retrospectively correlated the PIK3CA mutation status of patients with response rates from PI3K/Akt/mTOR inhibition. These authors observed higher responses in the PIK3CA mutant population (35\% partial responses) compared with the PIK3CA wild-type population (6\% partial responses) [66]. Targeting the PI3K pathway appears very promising, although more extensive study is required - particularly in identifying patients who will benefit. Novel agents targeting this pathway are listed in Table 4 . 


\section{Other potential targets}

Cyclin D1 is amplified in approximately $10 \%$ of breast cancer and is known to have a role in driving proliferation through its interaction with cyclin-dependent kinases such as CDK4 [67]; subsequently, it has been suggested that cyclin-directed therapies may have a role in luminalB subtypes, where proliferation is an important factor [67]. Cyclin inhibitors are currently in early-phase development.

Recent preclinical research has identified a potential breast cancer oncogene, ZNF703, implicated in the luminal-B subtype [68]. In this study ZNF703 was significantly amplified in luminal-B tumors, and its overexpression was associated with poor clinical outcome [68]. In cell lines, overexpression of ZNF703 induced cell proliferation independent of estradiol stimulation [68]. The investigators also observed that ZNF703 is ER regulated and may have a role in cancer stem cell selfrenewal [68], suggesting a potential role for ZNF703 inhibition in luminal-B breast cancer.

Another recent study has indicated an association between luminal-B tumors and overexpression of the scaffold protein NHERF1 (sodium-hydrogen exchanger regulatory factor 1). NHERF1 expression is associated with poorer survival and resistance to endocrine therapy in ER-positive breast cancer [69]. Further study is required to determine whether NHERF1 is an appropriate candidate for targeted therapy.

\section{Conclusion}

Gene expression studies have led to the identification of luminal-B breast cancer, a subtype of ER-positive breast cancer defined by increased proliferation, relative resistance to chemotherapy compared with other highly proliferative breast cancers, and poor outcome with endocrine therapy. Assigning the luminal-B subtype to individual breast cancers has been problematic, however, as the robustness of single subtype classifiers is suboptimal. Rather than approaching luminal-B cancer as a fixed biological entity, it is more clinically useful to consider the luminal-B phenotype as a conceptual framework, recognizing that proliferation in ER-positive/ HER2-negative tumors exists along a continuum. Identification of highly proliferative ER-positive/HER2negative tumors - whether through histological grading, the Ki-67 labeling index, or a multigene signature - is useful to separate aggressive luminal-B-like tumors with a risk of early relapse from more indolent luminal-A-like tumors that are adequately treated with endocrine therapy alone. In an effort to improve survival in luminal$B$ breast cancer, there has been a recent focus on particular molecular pathways where development of efficacious therapeutic agents may alter the natural history of the disease. For these novel treatments to have their desired effect, however, additional work is needed to characterize the drivers of aggressive biology, and future trials should acknowledge the molecular heterogeneity of ER-positive breast cancer and separate the more indolent luminal-A breast cancers from their more proliferative luminal-B-like counterparts.

\section{Abbreviations \\ CDNA, complementary DNA; ER, estrogen receptor; FGF, fibroblast growth factor; FGFR, fibroblast growth factor receptor; IGF-1, insulin-like growth factor 1; IGF-1R, insulin-like growth factor 1 receptor; mTOR, mammalian target of rapamycin; PCR, pathological complete response; PI3K, phosphoinositide 3-kinase; PIK3CA, phosphoinositide 3-kinase catalytic alpha; PR, progesterone receptor; RFS, relapse-free survival; SNP, single nucleotide polymorphism; SSP, single sample predictor.}

\section{Competing interests}

BT declares that he has no competing interests. PLB declares research funding from Novartis, BristolMyersSquibb, and GlaxoSmithKline, and consultancy funding from Roche, Sanofi-Aventis and Johnson and Johnson.

\section{Published: 30 November 2011}

\section{References}

1. National Cancer Institute [http://www.cancer.gov/dictionary?CdrID=561717]

2. Fisher B, Costantino J, Redmond C, Poisson R, Bowman D, Couture J, Dimitrov NV, Wolmark N, Wickerham DL, Fisher ER: A randomized clinical trial evaluating tamoxifen in the treatment of patients with node-negative breast cancer who have estrogen-receptor-positive tumors. N Engl J Med 1989, 320:479-784

3. Slamon DJ, Leyland-Jones B, Shak S, Fuchs H, Paton V, Bajamonde A, Fleming T, Eiermann W, Wolter J, Pegram M, Baselga J, Norton L: Use of chemotherapy plus a monoclonal antibody against HER2 for metastatic breast cancer that overexpresses HER2. N Engl J Med 2001, 344:783-792.

4. Geyer CE, Forster J, Lindquist D, Chan S, Romieu CG, Pienkowski T, JagielloGruszfeld A, Crown J, Chan A, Kaufman B, Skarlos D, Campone M, Davidson N, Berger M, Oliva C, Rubin SD, Stein S, Cameron D: Lapatinib plus capecitabine for HER2-positive advanced breast cancer. NEngl J Med 2006, 355:2733-2743.

5. Wirapati P, Sotiriou C, Kunkel S, Farmer P, Pradervand S, Haibe-Kains B, Desmedt C, Ignatiadis M, Sengstag T, Schütz F, Goldstein DR, Piccart M, Delorenzi M: Meta-analysis of gene expression profiles in breast cancer: toward a unified understanding of breast cancer subtyping and prognosis signatures. Breast Cancer Res 2008, 10:R65.

6. Sorlie T, Tibshirani R, Parker J, Hastie T, Marron JS, Nobel A, Deng S, Johnsen H, Pesich R, Geisler S, Demeter J, Perou CM, Lønning PE, Brown PO, BørresenDale AL, Botstein D: Repeated observation of breast tumor subtypes in independent gene expression data sets. Proc Natl Acad Sci U S A 2003, 100:8418-8423.

7. Perou CM, Sørlie T, Eisen MB, van de Rijn M, Jeffrey SS, Rees CA, Pollack JR, Ross DT, Johnsen H, Akslen LA, Fluge O, Pergamenschikov A, Williams C, Zhu SX, Lønning PE, Børresen-Dale AL, Brown PO, Botstein D: Molecular portraits of human breast tumours. Nature 2000, 406:747-752.

8. Sørlie T, Perou CM, Tibshirani R, Aas T, Geisler S, Johnsen H, Hastie T, Eisen MB, van de Rijn M, Jeffrey SS, Thorsen T, Quist H, Matese JC, Brown PO, Botstein D, Lønning $P E$, Børresen-Dale AL: Gene expression patterns of breast carcinomas distinguish tumor subclasses with clinical implications. Proc Natl Acad Sci U S A 2001, 98:10869-10874.

9. Sotiriou C, Pusztai L: Gene-expression signatures in breast cancer. N Eng/J Med 2009, 360:790-800

10. Brenton JD, Carey LA, Ahmed AA, Caldas C: Molecular classification and molecular forecasting of breast cancer: ready for clinical application? J Clin Oncol 2005, 23:7350-7360.

11. Loi S, Sotiriou C, Haibe-Kains B, Lallemand F, Conus NM, Piccart MJ, Speed TP, McArthur GA: Gene expression profiling identifies activated growth factor signaling in poor prognosis (Luminal-B) estrogen receptor positive breast cancer. BMC Med Genomics 2009, 2:37.

12. Cheang MCU, Chia SK, VoduC D, Gao D, Leung S, Snider J, Watson M, Davies S, Bernard PS, Parker JS, Perou CM, Ellis MJ, Nielsen TO: Ki67 index, HER2 status, and prognosis of patients with luminal B breast cancer. J Natl Cancer Inst 
2009, 101:736-750

13. Hu Z, Fan C, Oh DS, Marron JS, He X, Qaqish BF, Livasy C, Carey LA, Reynolds E, Dressler L, Nobel A, Parker J, Ewend MG, Sawyer LR, Wu J, Liu Y, Nanda R, Tretiakova M, Ruiz Orrico A, Dreher D, Palazzo JP, Perreard L, Nelson E, Mone M, Hansen H, Mullins M, Quackenbush JF, Ellis MJ, Olopade OI, Bernard PS, Perou CM: The molecular portraits of breast tumors are conserved across microarray platforms. BMC Genomics 2006, 7:96.

14. Parker JS, Mullins M, Cheang MCU, Leung S, Voduc D, Vickery T, Davies S, Fauron C, He X, Hu Z, Quackenbush JF, Stijleman IJ, Palazzo J, Marron JS, Nobel AN, Mardis E, Nielsen TO, Ellis MJ, Perou CM, Bernard PS: Supervised risk predictor of breast cancer based on intrinsic subtypes. J Clin Oncol 2009, 27:1160-1167

15. Mackay A, Weigelt B, Grigoriadis A, Kreike B, Natrajan R, A'hern R, Tan DSP, Dowsett M, Ashworth A, Reis-Filho JS: Microarray-based class discovery for molecular classification of breast cancer: analysis of interobserver agreement. J Natl Cancer Inst 2011, 103:662-673.

16. Weigelt B, Mackay A, A'hern R, Natrajan R, Tan DS, Dowsett M, Ashworth A Reis-Filho JS: Breast cancer molecular profiling with single sample predictors: a retrospective analysis. Lancet Oncol 2010, 11:339-349.

17. Desmedt C, Haibe-Kains B, Wirapati P, Buyse M, Larsimont D, Bontempi G, Delorenzi M, Piccart MJ, Sotiriou C: Biological processes associated with breast cancer clinical outcome depend on the molecular subtypes. Clin Cancer Res 2008, 14:5158-5165.

18. Loi S, Haibe-Kains B, Desmedt C, Lallemand F, Tutt AM, Gillet C, Ellis P, Harris A, Bergh J, Foekens JA, Klijn JGM, Larsimont D, Buyse M, Bontempi G, Delorenzi M, Piccart MJ, Sotiriou C: Definition of clinically distinct molecular subtypes in estrogen receptor-positive breast carcinomas through genomic grade. $J$ Clin Oncol 2007, 25:1239-1246.

19. Collins LC, Botero ML, Schnitt SJ: Bimodal frequency distribution of estrogen receptor immunohistochemical staining results in breast cancer. Am J Clin Pathol 2005, 123:16-20.

20. Nishimura R, Arima N: Clinical significance of proliferative activity evaluated by MIB-1 in the treatment and postoperative follow-up of early breast cancer [abstract]. J Clin Oncol 2007, 18S:20154

21. Ignatiadis M, Bedard P, Haibe-Kains B, SinghI S, Loi S, Criscitiello C, Desmedt C, Bontempi G, Piccart M, Sotiriou C: A meta-analysis of gene expression profiling studies identifies clinically relevant oncogenic pathways in basallike breast cancer [abstract]. Cancer Res 2009, 69:S106.

22. Leyland-Jones B: Human epidermal growth factor receptor 2-positive breast cancer and central nervous system metastases. J Clin Oncol 2009, 27:5278-5286

23. Gabos Z Sinha R, Hanson J Chauhan N, Hugh J, Mackey JR, Abdulkarim B: Prognostic significance of human epidermal growth factor receptor positivity for the development of brain metastasis after newly diagnosed breast cancer. J Clin Oncol 2006, 24:5658-5663.

24. Smid M, Wang Y, Zhang Y, Sieuwerts AM, Yu J, Klijn JGM, Foekens JA, Martens JWM: Subtypes of breast cancer show preferential site of relapse. Cancer Res 2008, 68:3108-3114.

25. Esserman L, Perou C, Cheang M, DeMichele A, Carey L, Van 't Veer L, Gray J, Petricoin E, Conway K, Hylton N, Berry D: Breast cancer molecular profiles and tumor response of neoadjuvant doxorubicin and paclitaxel: the I-SPY TRIAL (CALGB 150007/150012, ACRIN 6657). J Clin Oncol 2009, 27:LBA515.

26. de Ronde J., Hannemann J, Halfwerk H, Mulder L, Straver ME, Vrancken Peeters MJTFD, Wesseling J, van de Vijver M, Wessels LFA, Rodenhuis S: Concordance of clinical and molecular breast cancer subtyping in the context of preoperative chemotherapy response. Breast Cancer Res Treat 2010, 119:119-126.

27. Bhargava R, Beriwal S, Dabbs DJ, Ozbek U, Soran A, Johnson RR, Brufsky AM, Lembersky BC, Ahrendt GM: Immunohistochemical surrogate markers of breast cancer molecular classes predicts response to neoadjuvant chemotherapy: a single institutional experience with 359 cases. Cancer 2010, 116:1431-1439.

28. Carey L, Dees EC, Sawyer L, Gatti L, Moore DT, Collichio F, Ollila DW, Sartor Cl, Graham ML, Perou CM: The triple negative paradox: primary tumor chemosensitivity of breast cancer subtypes. Clin Cancer Res 2007 13:2329-2334

29. Rouzier R, Perou CM, Symmans WF, Ibrahim N, Cristofanilli M, Anderson K, Hess KR, Stec J, Ayers M, Wagner P, Morandi P, Fan C, Rabiul I, Ross JS, Hortobagyi GN, Pusztai L: Breast cancer molecular subtypes respond differently to preoperative chemotherapy. Clin Cancer Res 2005 11:5678-5685.
30. Liedtke C, Mazouni C, Hess KR, André F, Tordai A, Mejia JA, Symmans WF, Gonzalez-Angulo AM, Hennessy B, Green M, Cristofanilli M, Hortobagyi GN, Pusztai L: Response to neoadjuvant therapy and long-term survival in patients with triple-negative breast cancer. J Clin Oncol 2008, 26:1275-1281

31. Andre F, Mazouni C, Liedtke C, Kau SW, Frye D, Green M, Gonzalez-Angulo AM, Symmans WF, Hortobagyi GN, Pusztai L: HER2 expression and efficacy of preoperative paclitaxel/FAC chemotherapy in breast cancer. Breast Cancer Res Treat 2008, 108:183-190

32. Paik S, Tang G, Shak S, Kim C, Baker J, Kim W, Cronin M, Baehner FL, Watson D, Bryant J, Costantino JP, Geyer CE, Wickerham DL, Wolmark N: Gene expression and benefit of chemotherapy in women with node-negative, estrogen receptor-positive breast cancer. J Clin Oncol 2006, 24:3726-3734.

33. Ellis MJ, Tao Y, Luo J, A'Hern R, Evans DB, Bhatnagar AS, Chaudri-Ross HA, von Kameke A, Miller WR, Smith I, Eiermann W, Dowsett M: Outcome prediction for estrogen receptor-positive breast cancer based on postneoadjuvant endocrine therapy tumor characteristics. J Nat/ Cancer Inst 2008, 100:1380-1388.

34. Dowsett M, Smith IE, Ebbs SR, Dixon JM, Skene A, A'Hern R, Salter J, Detre S, Hills M, Walsh G: Prognostic value of Ki67 expression after short-term presurgical endocrine therapy for primary breast cancer. J Natl Cancer Inst 2007, 99:167-170.

35. Eiermann W, Paepke S, Appfelstaedt J, Llombart-Cussac A, Eremin J, Vinholes J, Mauriac L, Ellis M, Lassus M, Chaudri-Ross HA, Dugan M, Borgs M: Preoperative treatment of postmenopausal breast cancer patients with letrozole: a randomized double-blind multicenter study. Annals Oncol 2001, 12:1527-1532.

36. Baselga J, Semiglazov V, van Dam P, Manikhas A, Bellet M, Mayordomo J, Campone M, Kubista E, Greil R, Bianchi G, Steinseifer J, Molloy B, Tokaji E, Gardner H, Phillips P, Stumm M, Lane HA, Dixon M, Jonat W, Rugo HS: Phase II randomized study of neoadjuvant everolimus plus letrozole compared with placebo plus letrozole in patients with estrogen receptor-positive breast cancer. J Clin Oncol 2009, 27:2630-2637.

37. Semiglazov VF, Semiglazov V, Dashyan GA, Ziltsova EK, Ivanov VG, Bozhok AA, Melnikova OA, Paltuev RM, Kletzel A, Berstein LM: Phase 2 randomized trial of primary endocrine therapy versus chemotherapy in postmenopausal patients with estrogen receptor-positive breast cancer. Cancer 2007, 110:244-254

38. Harris L, Fritsche H, Mennel R, Norton L, Ravdin P, Taube S, Somerfield MR, Hayes DF, Bast RC: American Society of Clinical Oncology 2007 update of recommendations for the use of tumor markers in breast cancer. $J$ Clin Oncol 2007, 25:5287-5312.

39. Albain KS, Barlow WE, Shak S, Hortobagyi GN, Livingston RB, Yeh IT, Ravdin P, Bugarini R, Baehner FL, Davidson NE: Prognostic and predictive value of the 21-gene recurrence score assay in postmenopausal women with nodepositive, oestrogen-receptor-positive breast cancer on chemotherapy: a retrospective analysis of a randomised trial. Lancet Oncol 2010, 11:55-65.

40. Pollak M: Insulin and insulin-like growth factor signalling in neoplasia. Nat Rev Cancer 2008, 8:915-928.

41. Peyrat J, Louchez M, Lefebvre J, Bonneterre J, Vennin P, Demaille A, Helquet B, Fournier C: Plasma insulin-like growth factor-1 (IGF-1) concentrations in human breast cancer. Eur J Cancer 1993, 29:492-497.

42. Shimizu C, Hasegawa T, Tani Y, Takahashi F, Takeuchi M, Watanabe T, Ando M, Katsumata N, Fujiwara Y: Expression of insulin-like growth factor 1 receptor in primary breast cancer: immunohistochemical analysis. Hum Pathol 2004, 35:1537-1542.

43. Law JH, Habibi G, Hu K, Masoudi H, Wang MYC, Stratford AL, Park E, Gee JMW, Finlay P, Jones HE, Nicholson RI, Carboni J, Gottardis M, Pollak M, Dunn SE: Phosphorylated insulin-like growth factor-l/insulin receptor is present in all breast cancer subtypes and is related to poor survival. Cancer Res 2008 68:10238-10246.

44. Creighton CJ, Casa A, Lazard Z, Huang S, Tsimelzon A, Hilsenbeck SG, Osborne CK, Lee AV: Insulin-like growth factor-I activates gene transcription programs strongly associated with poor breast cancer prognosis. J Clin Oncol 2008, 26:4078-4085.

45. Ignatiadis M, Haibe-Keins B, Bedard P, Singhal S, Lallemand F, Desmedt C, Cardoso F, Piccart M, Sotiriou C: Gene expression module associated with insulin-like growth factor 1 (IGF1) pathway activation predicts poor response to tamoxifen in women with $\mathrm{ER}^{+} / \mathrm{HER}^{-}$early breast cancer $(\mathrm{BC})$ [abstract]. Proc Am Assoc Cancer Res 2009 Apr 18-22; Denver, CO. Philadelphia (PA): AACR; 2009. Abstract 2743.

46. Lisztwan J, Pornon A, Chen B, Chen S, Evans DB: The aromatase inhibitor 
letrozole and inhibitors of insulin-like growth factor I receptor synergistically induce apoptosis in in vitro models of estrogen-dependent breast cancer. Breast Cancer Res 2008, 10:R56.

47. Atzori F, Traina T a, lonta MT, Massidda B: Targeting insulin-like growth factor type 1 receptor in cancer therapy. Targeted Oncol 2009, 4:255-266.

48. Kaufman PA, Ferrero JM, Bourgeois H, Kennecke H, De Boer R, Jacot W, McGreivy J, Suzuki S, Loh E, Robertson J: A randomized, double-blind, placebo-controlled, phase 2 study of AMG 479 with exemestane (E) or fulvestrant $(F)$ in postmenopausal women with hormone-receptor positive $\left(\mathrm{HR}^{+}\right)$metastatic $(\mathrm{M})$ or locally advanced $(\mathrm{LA})$ breast cancer $(\mathrm{BC})$ [abstract]. Cancer Res 2010, 70(24 Suppl):Abstract S1-4.

49. Hynes NE, Dey JH: Potential for targeting the fibroblast growth factor receptors in breast cancer. Cancer Res 2010, 70:5199-5202.

50. Casanovas O, Hicklin DJ, Bergers G, Hanahan D: Drug resistance by evasion of antiangiogenic targeting of VEGF signaling in late-stage pancreatic islet tumors. Cancer Cell 2005, 8:299-309.

51. Presta M, Dell'Era P, Mitola S, Moroni E, Ronca R, Rusnati M: Fibroblast growth factor/fibroblast growth factor receptor system in angiogenesis. Cytokine Growth Factor Rev 2005, 16:159-178.

52. Turner N, Grose R: Fibroblast growth factor signalling: from development to cancer. Nat Rev Cancer 2010, 10:116-129.

53. Turner N, Pearson A, Sharpe R, Lambros M, Geyer F, Lopez-Garcia MA, Natrajan R, Marchio C, lorns E, Mackay A, Gillett C, Grigoriadis A, Tutt A, ReisFilho JS, Ashworth A: FGFR1 amplification drives endocrine therapy resistance and is a therapeutic target in breast cancer. Cancer Res 2010, 70:2085-2094

54. Reis-Filho JS, Simpson PT, Turner NC, Lambros MB, Jones C, Mackay A, Grigoriadis A, Sarrio D, Savage K, Dexter T, Iravani M, Fenwick K, Weber B, Hardisson D, Schmitt FC, Palacios J, Lakhani SR, Ashworth A: FGFR1 emerges as a potential therapeutic target for lobular breast carcinomas. Clin Cancer Res 2006, 12:6652-6662.

55. Shiang CY, Qi Y, Wang B, Lazar V, Wang J, Fraser Symmans W, Hortobagyi GN, Andre F, Pusztai L: Amplification of fibroblast growth factor receptor-1 in breast cancer and the effects of brivanib alaninate. Breast Cancer Res Treat 2009, 123:747-755.

56. Fry MJ: Phosphoinositide 3-kinase signalling in breast cancer: how big a role might it play? Breast Cancer Res 2001, 3:304-312.

57. Lee JW, Soung YH, Kim SY, Lee HW, Park WS, Nam SW, Kim SH, Lee JY, Yoo NJ, Lee SH: PIK3CA gene is frequently mutated in breast carcinomas and hepatocellular carcinomas. Oncogene 2005, 24:1477-1480.

58. Loi S, Haibe-kains B, Majjaj S, Lallemand F, Durbecq V, Larsimont D: PIK3CA mutations associated with gene signature of low mTORC1 signaling and better outcomes in estrogen receptor-positive breast cancer. Proc Natl Acad Sci U S A 2010 [Epub ahead of print].

59. Creighton CJ, Fu X, Hennessy BT, Casa AJ, Zhang Y, Gonzalez-Angulo AM, Lluch A, Gray JW, Brown PH, Hilsenbeck SG, Osborne CK, Mills GB, Lee AV, Schiff R: Proteomic and transcriptomic profiling reveals a link between the $\mathrm{PI3K}$ pathway and lower estrogen-receptor (ER) levels and activity in $\mathrm{ER}^{+}$ breast cancer. Breast Cancer Res 2010, 12:R40.
60. Baselga J: Targeting the phosphoinositide-3 (PI3) kinase pathway in breast cancer. Oncologist 2011, 16(Suppl 1):12-19.

61. Tabernero J, Rojo F, Calvo E, Burris H, Judson I, Hazell K, Martinelli E, Ramon YCS, Jones S, Vidal L, Shand N, Macarulla T, Ramos FJ, Dimitrijevic S, Zoellner U, Tang P, Stumm M, Lane HA, Lebwohl D, Baselga J: Dose- and scheduledependent inhibition of the mammalian target of rapamycin pathway with everolimus: a phase I tumor pharmacodynamic study in patients with advanced solid tumors. J Clin Oncol 2008, 26:1603-1610.

62. Kurmasheva T, Boltz C, Phelps D, Morton C, Houghton P: Combination of CP-751871, a human monoclonal antibody agalnstitute the IGF-1 receptor, with rapamycin results in a highly effective therapy for xenografts derived from childhood sarcomas [abstract]. AACR-NCI-EORTC International Conference on Molecular Targets and Cancer Therapeutics; 2007; San Francisco (CA); 2007. Abstract C172.

63. Darko I, Yeung C, Wan X, Helman L, Khanna C: Evaluation of combined insulin-like growth factor type 1 (IGF1R) and mTOR pathway blockade in sarcoma xenograft models. AACR Meeting Abstracts 2007, 2007:4760.

64. Di Cosimo S, Bendell JC, Cervantes-Ruiperez A, Roda D, Prudkin L, Stein MN, Leighton-Swayze A, Song Y, Ebbinghaus S, Baselga J: A phase I study of the oral mTOR inhibitor ridaforolimus (RIDA) in combination with the IGF-1R antibody dalotozumab (DALO) in patients (pts) with advanced solid tumors [abstract]. J Clin Oncol 2010, 28S:3008.

65. Weigelt B, Warne PH, Downward J: PIK3CA mutation, but not PTEN loss of function, determines the sensitivity of breast cancer cells to mTOR inhibitory drugs. Oncogene 2011, 30:3222-3233.

66. Janku F, Tsimberidou A, Garrido-Laguna I, Wang X, Luthra R, Hong DS, Naing A, Falchook GS, Moroney JW, Piha-Paul Sa, Wheler JJ, Moulder SL, Fu S, Kurzrock R: PIK3CA mutations in patients with advanced cancers treated with PIK3/AKT/mTOR axis inhibitors. Mol Cancer Ther 2011, 10:558-65.

67. Jeselsohn R, Brown NE, Arendt L, Klebba I, Hu MG, Kuperwasser C, Hinds PW: Cyclin $D$, kinase activity is required for the self-renewal of mammary stem and progenitor cells that are targets of MMTV-ErbB2 tumorigenesis. Cancer Cell 2010, 17:65-76.

68. Sircoulomb F, Nicolas N, Ferrari A, Finetti F, Bekhouche I, Rousselet E, Lonigro A, Adélaïde J, Baudelet E, Esteyriès S, Wicinski J, Audebert S, Charafe-Jauffret E, Jacquemier J, Lopez M, Borg JP, Sotiriou C, Popovici C, Bertucci F, Birnbaum D, Chaffanet M, Ginestie C: ZNF703 gene amplification at 8p12 specifies luminal B breast cancer. EMBO Mol Med 2011, 33:1-47.

69. Karn T, Ruckhäberle E, Hanker L, Müller V, Schmidt M, Solbach C, Gätje R, Gehrmann M, Holtrich U, Kaufmann M, Rody A: Gene expression profiling of luminal $B$ breast cancers reveals NHERF1 as a new marker of endocrine resistance. Breast Cancer Res Treat 2011 [Epub ahead of print].

doi:10.1186/bcr2904

Cite this article as: Tran B, Bedard PL: Luminal-B breast cancer and novel

therapeutic targets. Breast Cancer Research 2011, 13:221. 